\title{
SISTEM EKONOMI KAPITALISME
}

\section{Inatul Hinaya (90100118036)}

Kapitalisme adalah sebuah sistem organisasi ekonomi yang bercirikan hak milik pribadi atas alat-alat produksi dan distribusi yang pemanfaatannya untuk mencapai laba dalam kondisi yang sangat kompetitif(Itok \& Sri, 2017). Kapitalisme sebagai sistem ekonomi muncul pada abad ke 16, yang didorong dengan kemunculan industri sandang di Inggris. Bahan baku wool yang diproduksi di dalam negeri menjadi hal yang mendorong perkembangan industri yang ada di Inggris. Kapitalisme berkembang ketika terjadi revolusi industri di Inggris yang di tandai dengan adanya peralihan dari dominasi modal perdagangan di atas modal bagi setiap industri yang mengarah ke dominasi modal industri atas modal perdagangan(Effendi, 2019). Dasar filosofis pemikiran ekonomi Kapitalis berasal dari sebuah tulisan Adam Smith pada tahun 1776 dalam bukunya An Inquiry into the Nature and Causes of the Wealth of Nations. Isi buku tersebut sejalan dengan tingkah laku ekonomi dalam masyarakat, yang selanjutnya menjadi sebuah sistem ekonomi, dan mengakar menjadi ideologi yang mencerminkan gaya hidup (way of life). Smith berpendapat bahwa manusia dalam menjalankan kegiatan ekonomi dikarenakan adanya dorongan yang menjadi kepentingan pribadi, yang bertindak sebagai tenaga pendorong dan mengarahkan manusia dalam mengerjakan segala hal asal masyarakat senantiasa membayar. Alasan kepentingan individu yang didorong oleh filsafat liberalisme selanjutnya menciptakan sistem ekonomi pasar bebas, yang pada akhirnya melahirkan ekonomi Kapitalis(Hamron, 2009).

Pasar menjadi pemilik peranan yang teramat penting pada sistem perekonomian dalam ekonomi kapitalis. Ekonomi kapitalis menginginkan pasar bebas menjadi solusi dalam hal penyelesaian setiap masalah yang ada dalam ekonomi seperti halnya produksi, konsumsi maupun distribusi. Perilaku kapitalis membiarkan perekonomian berjalan dengan semestinya tanpa ada intervensi dari pemerintah, dan yang akan membawa perekonomian ke arah keseimbangan adalah dengan adanya tangan-tangan 
tak terlihat atau yang sering disebut dengan invisible hands. Apabila ada campur tangan dari pemerintah, maka pasar akan mengalami distorsi yang pada akhirnya akan menjadikan perekonomian menjadi tidak efisien dan tidak seimbang. Prinsip pasar bebas ini akan menghasilkan keseimbangan dalam masyarakat, karena akan menghasilkan gaji yang adil, harga barang yang relatif stabil dan menjadikan tingkat pengangguran semakin rendah. Oleh karena sebab itu maka fungsi dari sebuah negara dalam hal ekonomi sama sekali harus dikurangi, karena jikalau negara ikut campur dalam ekonomi maka akan menghilangkan sektor swasta dan pada akhirnya akan mengganggu keseimbangan pasar(Parakkasi \& Kamiruddin, 2018).

Kelebihan dari sistem ekonomi kapitalisme antara lain : mendorong terjadinya pertumbuhan ekonomi dengan memfasilitasi persaingan terbuka di dalam pasar, menyediakan kesempatan bagi setiap orang agar lebih baik untuk meningkatkan pendapatan, merupakan sebuah sistem ekonomi yang terdesentralisasi sehingga dalam berbisnis para individu dapat memiliki lebih banyak pilihan, harus menghadapi hambatan yang berbeda dan juga diharuskan untuk menemukan solusi agar mampu unggul dalam kompetisi, setiap pengusaha dengan kinerja yang baik dan bisa berinovasi secara terus-menerus akan menjadi pemenang dalam persaingan, membentuk ekonomi dimana konsumen yang mengatur pasar, dan membuat konsumen memiliki lebih banyak pilihan serta mendorong orang untuk mencapai kebebasan finansial. Selain memiliki kelebihan, terdapat pula kekurangan dari sistem ekonomi kapitalisme ini yaitu : Adanya persaingan tidak sehat, menjadikan ekonomi hanya berorientasi pada uang, keuntungan dipandang menjadi tujuan bisnis utama dengan rekayasa bisnis mengambil alih perusahaan-perusahaan kecil, Tenaga kerja dikompensasi dengan tujuan satu-satunya agar memiliki produktivitas yang lebih tinggi, menjadikan sumber daya alam semakin menipis karena dieksploitasi untuk menjaga pertumbuhan ekonomi yang berkesinambungan, serta menyebabkan distribusi kekayaan yang tidak adil dengan kekayaan dan kekuasaan hanya dikuasai oleh segelintir orang(Tho'in, 2015) . 


\section{DAFTAR PUSTAKA}

Effendi, S. (2019). Perbandingan Sistem Ekonomi Islam Dengan Sistem Ekonomi Kapitalis dan Sosialis. JRAM (Jurnal Riset Akuntansi Multiparadigma), 6(2), 147158.

Kurniawan, I. D., \& Lahir, S. (2017). Sistem Kapitalisme Negara sebagai Alternatif Sistem Ekonomi Kerakyatan Berdasarkan Pancasila. Jurnal Ilmiah Edunomika, 1(02), 84-99.

Parakkasi, I., \& Kamiruddin, K. (2018). ANALISIS HARGA DAN MEKANISME PASAR DALAM PERSPEKTIF ISLAM. Laa Maisyir: Jurnal Ekonomi Islam, 5(1), 107-120.

Tho'in, M. (2015). Konsep Ekonomi Islam Jalan Tengah (Kapitalis-Sosialis). Jurnal Ilmiah Ekonomi Islam, 1(03), 118-133.

Zubadi, H. (2009). Perlunya Pengenalan Pendidikan Sistem Ekonomi Islam dengan Sistem Ekonomi yang Lain Sejak Dini. Jurnal Fakultas Ekonomi Universitas Muhammadiyah Magelang, 1(3), 150-157. 